\title{
MENANGKAL RADIKALISME DENGAN PENGUATAN PENDIDIKAN KARAKTER NASIONALISME MELALUI AMALIYAH ASWAJA DI SD ISLAMIYAH MAGETAN
}

\author{
Irwan Fathurrochman', Abu Muslim² \\ ${ }^{1}$ Institut Agama Islam Negeri Curup \\ ${ }^{2}$ Institut Agama Islam Negeri Ponorogo \\ *Corresponding Address: irwan@iaincurup.ac.id
}

Naskah diterima: 9 Desember 2021| Disetujui: 20 Desember 2021 | Diterbitkan: 22 Desember 2021

\begin{abstract}
Abstrack: This study explains how the implementation of strengthening nationalism character education and what factors influence the implementation of nationalism character with Aswaja amaliyah as counter radicalism in SD Islamiyah Magetan. Then what are the impacts on counter radicalism? All these questions will be answered by researchers using a qualitative approach. This research uses descriptive analytical thinking method with field research. The results of this study are that students are able to fortify themselves from the influence of radicalism that spreads in schools and schools. The inhibiting factor is the influence of social media which is often accessed by students from propaganda. Meanwhile, another supporting factor is the commitment to the parents of students through good communication towards understanding the importance of nationalism character education through Amaliah Aswaja. So that it is hoped that it can support nationalism character education through Amaliah Aswaja able to ward off radicalism.
\end{abstract}

Keywords: Character Education, Radicalism, Amaliyah Aswaja

\begin{abstract}
Abstrak: Penelitian ini menjelaskan bagaimana pelaksanan penguatan pendidikan karakter nasionalisme dan faktor apa saja yang mempengaruhi pelaksanaan karakter nasionalisme dengan amaliyah Aswaja sebagai kontra radikalisme di SD Islamiyah Magetan, serta apa saja dampak yang ditimbulkan terhadap kontra radikalisme. Masalah tersebut akan dijabarkan peneliti menggunakan pendekatan kualitatif. Penelitian ini menggunakan metode berfikir deskriptif analitis dengan penelitian lapangan. Hasil dari penelitian ini adalah bahwa peserta didik mampu membentengi diri dari pengaruh radikalisme yang menyebar di sekolah maupun masyarakat. Faktor penghambatnya adalah pengaruh media sosial yang sering diakses siswa yang terkadang mengandung propaganda. Sedangkan faktor pendukung lainya adalah komitmen dengan orang tua peserta didik melalui komunikasi yang baik terhadap pemahaman pengutan pendidikan karakter nasionalisme melalui amaliah Aswaja, sehingga diharapkan pelaksanaan penguatan pendidikan karakter nasionalisme melalui amaliah Aswaja mampu menangkal radikalisme.
\end{abstract}

Kata kunci: Pendidikan Karakter, Radikalisme, Amaliyah Aswaja 


\section{PENDAHULUAN}

Pendidikan karakter merupakan nilai-nilai karakter dari peserta didik yang dikembangkan dalam pendidikan. Tujuan Pendidikan karakter menjadikan siswa memiliki nilai dan karakter pada dirinnya, sehingga dapat diterapkan dalam kehidupan sosial masyarakat (Zubaedi, 2011). Proses pendidikan karakter meliputi relasi antara dimensi sosial dengan moral, sebagai bentuk pondasi dalam kehidupan sehari-hari sehingga dapat terbentuk generasi masa kini yang berakhlakul karimah dan mampu untuk mandiri hingga memiliki prinsip tanggung jawab kepada dirinya sendiri maupun bangsa negara (Nasional, 2010).

Pendidikan karakter bisa diwujudkan dari potensi manusia yang memiliki sinergisitas yang meliputi aspek afektif, kognitif, serta psikomotorik yang mempunyai fungsi psikologis dan fungsi sosial kultural, baik dalam satuan pendidikan maupu lingkungan keluarga hingga masyarakat. Wujud dari pendidikan karakter dapat dikelompokkan pada olah pikir (intellectual developmental), olah jiwa (spiritual and emotional developmental), olah rasa dan karsa (affective and creativity developmental), serta kinestetik dan olah raga (physical and kinestetic developmental). Secara keseluruhan keempat proses psikososial tersebut saling melengkapi dan memiliki keberlanjutan yang bermuara pada pembentukan nilai karakter yang luhur (Nasional, 2010).

Tidak dapat dipungkiri persoalan era saat ini pada anak-anak yang penting diperhatikan adalah tindakan pembangkangan terhadap negara. Persoalaan ini disebabkan anak-anak melakukan tindak tersebut karena kurangnya penanaman terhadap rasa cinta tanah air atau nasionalisme. Selain itu, kemunculan paham radikal juga menjadi pendorong dan menurunkan karakter nasionalisme yang berkembang pada anak-anak. Persoalan tersebut dapat dilihat seperti kasus di Yogyakarta bahwa seorang anak histeris ketakutan hingga mengagetkan orang tuanya, sebab anak bertanya kepada orang tuannya "Pah...nanti kalau Palestina diserang Israel, kita juga ikut mati enggak Pah?',". Lalu orang tuannya bertanya pada anak perihal tersebut dari mana asal muasal pertanyaan tersebut. Anaknya menjawab dan membuat terkejut, bahwa anak mengetahui informasi tersebut dari gurunya di sekolah (Radikalisme Berbalut Pendidikan Sudah Menyasar Anak Usia Dini di Indonesia - ABC Tempo.co).

Selain kasus di atas, terkait kemuculan embrio radikalisme dalam pendidikan juga terjadi di Probolinggo. Di mana kota ini menggelar pawai karnaval PAUD dan TK untuk memperingati HUT Kemerdekaan RI ke-73, pada pawai tersebut menjadi viral di sosial media karena salah satu peserta TK menggunakan cadar dan mengenakan jubah sambil memegang senjata mainan. Padahal hal tersebut identik dengan kelompok-kelompok radikal yang berkembang seperti HTI dan kelompok pembangkang lainnya. Meski demikian, guru TK tersebut menjelaskan busana dengan mengenakan penutup wajah agar sesuai topik perjuangan rasulullah pada masa dahulu dan untuk meningkatkan 
keimanan (Viral Peserta Karnaval TK Bercadar dan 'Bersenjata' di Probolinggo, 2018). Dari persoalan di atas, setidaknya dapat dilihat bagaimana pendidikan di Indonesia khususnya sekolah dasar mulai rawan tumbuhnya dan bekembangnya paham radikalisme.

Persoalan radikalisme di atas ternyata juga terdapat di Kabupaten Magetan. Terdapat 19 orang napi dan mantan napi kasus terorisme berasal dari Magetan. Menurut Bachrudin, Kasi Bimas Islam Kemenag Magetan, meski secara umum Kabupaten Magetan berideologi moderat, namun juga memliki tantangan seperti beberapa kasus radikalisme dan terorisme yang melibatkan warganya, sehingga menjadikan Magetan sebagai zona merah tumbuhnya radikalisme hingga terorisme. Pada tahun 1999 kelompok teroris sempat menjadi tempat latihan perang di Gunung Lawu (Haaa, Terduga Teroris Gatot Witono Pernah Dilatih Adik Amrozi di Gunung Lawu - Surya.co.id, 2016). Hal ini menunjukan bahwa di Kabupaten Magetan paham radikalisme sudah mulai berkembang.

Zuli Qodir mengatakan dengan mendasarkan pada pandangan Michael McCullough dan Timothy Smith bahwa kesehatan mental pada pribadi kaum milenial yang sangat rentan. Kaum muda sangat mudah jiwanya terguncang dikarenakan beberapa faktor dalam hidupnya. Beberapa guncangan jiwa yang muncul di antaranya karena ada tekanan atau kegagalan dalam hidup, sulit meraih kebahagiaan, relasi yang kurang baik dengan keluarga hingga memunculkan gangguan mental dan stres, sehingga di sinilah generasi muda berada di pihak yang begitu rentan (Usman, Qodir and Hasse, 2014).

Sementara itu, munculnya radikalisme Islam menurut Bassam Tibi bukan persoalan teologis, namun fenomena politik. Kata jihad sering digunakan kaum radikalis sebagai penguat atas pembenaran atas kepentingannya. Istilah tersebut mengalami pergeseran yang digaungkan oleh kelompok gerakan radikalis, sehingga ada perbedaan antara istilah "jihad" dan "jihadism". Pada zaman Rasulullah istilah jihad sudah muncul yang artinya perang sesuai aturan yang sudah jelas seperti tidak membunuh warga sipil dan anak-anak. Berbeda dengan istilah "jihadism" berarti pertempuran fisik hanya perang dan teror yang tidak batasan serta aturan yang jelas dibumbui oleh faktor kepentingan politik keagamaan (Tibi, 2012).

Hal ini bertolak belakang dengan rasa nasionalisme, sebab semangat nasionalisme merupakan sikap cinta tanah air. Nasionalisme tidak hanya instrumen yang bertujuan sebagai alat perekat kemajemukan secara eksternal, tapi juga sebagai tempat identitas yang menjelaskan sifat plural dalam berbagai dimensi kulturalnya. Dalam hal ini nasionalisme menghendaki perwujudan nilai-nilai dasar yang berfokus terhadap kepentingan kelompok dan menghindarkan dari segala bentuk kepentingan pribadi yang dapat merusak tatanan kehidupan yang multikultura (Junanto, 2013). 
Alwi Shihab menyatakan bahwa radikalisme dapat dilawan dengan melalui upaya penanaman nilai-nilai budaya, moderasi, toleransi, keseimbangan beragama, hingga keadilan dalam hubungan sosial. Hal ini dapat dimemaksimalkan peran keagamaan di sekolah seperti rohis, serta melakukan tindakan preventif dan preservatif terhadap Islam moderat dan kuratif (Shihab, 1999).

Dari fenomena paham radikalisme di atas, lembaga sekolah tentu perlu mengambil langkah antisipasi, baik pencegahan maupun penanggulangan. Seperti yang dilakukan di SD Islamiyah Magetan, setiap harinya diantisipasi dengan melakukan pembentukan karakter nasionalisme. SD Islamiyah Magetan memiliki keunikan yang tidak dimiliki oleh SD lain, yakni penanaman rasa nasionalisme dilakukan melalui kegiatan-kegiatan keagamaan amaliyah Aswaja. Seperti dengan menyanyikan lagu Ya Lal Wathon, dan mata ajar keagamaan kurikulum Aswaja. Bahkan setiap apel pagi diisi materi sejarah para pahlawan, sholat duha, dan kegiatan amaliyah lainnya seperti wirid, tahlil, asmaul husna, dan istigosah (Amaliyah Aswaja - SD Islamiyah Magetan, no 2020). Kegiatan tersebut merupakan kearifan lokal yang diyakini oleh guru dan lembaga sekolah tersebut sebagai bentuk penanaman pendidikan karakter nasionalisme. Dengan penuh semangat, mereka menjalankan kegiatan tersebut hingga menumbuhkan rasa cinta tanah air.

Berdasarkan logika di atas, penulis tertarik meneliti bagaimana implementasi penguatan pendidikan karakter nasionalisme hingga pengaruhnya sebagai upaya antisipasi pencegahan sekaligus bentuk kontra radikalisme siswa di SD Islamiyah Magetan. Tentu sangat mengkawatirkan jika merasuk pada jiwa dan kepribadian para anak atau pemuda sebagai generasi penerus bangsa. Sebab acap kali rekrutmen yang dilakukan para teroris mayoritas berasal dari anak-anak atau pemuda yang menjadi sasaran utama. Mereka dipandang sebagai generasi yang produktif dan mudah untuk dipengaruhi menjadi seorang pemberontak. Untuk mempermudah penulisan ini, maka penulis merumuskan masalah tentang bagaimana pelaksanaan penguatan pendidikan karakter nasionalisme dengan amaliyah Aswaja dan penangkal radikalisme terhadap siswa di SD Islamiyah Magetan. Penulis juga meneliti faktor-faktor apa saja yang mempengaruhi implementasi nilai-nilai karakter nasionalisme melalui amaliyah Aswaja terhadap kontra radikalisme di SD Islamiyah Magetan, serta bagaimana hubungan keduanya atas implementasi penguatan pendidikan karakkter nasionalisme melalui amaliyah Aswaja terhadap kontra radikalisme di SD Islamiyah Magetan.

\section{METODE}

Penelitian ini merupakan penelitian lapangan dengan memanfaatkan pendekatan kualitatif dan metode berfikir diskriptis analitis. Penelitian ini menggunakan pendekatan penguatan pendidikan karakter Kemendikbud. Kehadiran peneliti di lapangan guna menggali data dari informan. Ketika di 
lapangan peneliti menggali dua sumber, yakni data primer dan sekunder. Data primer digali melalui dari kegiatan-kegiatan tentang pelaksanaan amaliyah Aswaja, kegiatan keagamaan, dan strategi dalam menangkal faham radikalisme pada peserta didik dengan penguatan karakter nasionalisme melalui amaliyah Aswaja. Sedangkan data sekunder digali dari studi dokumen, arsip, dan naskah SD Islamiyah Magetan.

\section{HASIL DAN PEMBAHASAN}

\section{Pelaksanaan Penguatan Pendidikan Karekter Nasionalisme dengan Amaliah Aswaja dan Penangkal Radikalisme}

SD Islamiyah menerapkan penguatan pendidikan karekter (PPK) nasionalisme dengan amaliah Aswaja. PPK dapat dilaksanakan dengan tiga pendekatan yaitu berbasis kelas, berbasis budaya sekolah, dan berbasis masyarakat. Pertama, pengauatan pendidikan karakter berbasis kelas dapat mengintegrasikan PPK dalam mata pelajaran agama berhaluan Aswaja serta dalam bentuk manajemen kelas. Kedua, PPK berbasis budaya sekolah dilakukan tiap hari sabtu dengan melaksakan Amaliah NU yang telah terjadwal, pengembangan budaya sekolah, aturan sekolah, serta pengembangan kegiatan ekstrakurikuler (wajib dan pilihan). Ketiga, PPK berbasis masyarakat dengan menjalin kerjasama dengan organisasi atau komunitas keagamaan seperti IPNU atau IPPNU cabang NU Magetan atau lainnya.

\section{PPK Berbasis Kelas}

Setelah diteliti, temuan di SD Islamiyah Magetan dalam pelaksanakan penguatan pendidikan karakter nasionalisme dengan menerapkan kurikulum mata pelajaran agama berhaluan Aswaja yang disusun sendiri oleh lembaga pendidikan SD Islamiyah Magetan. Kurikulum Aswaja dalam buku ajar di kelas 1 b di semester 2, kelas 3 di semester 2, di kelas 5 a dan b di semester 1 dan 2 menjadi pedoman dalam kegiatan belajar mengajar.

Pembelajaran mata ajar agama berhaluan Aswaja merupakan penjabaran secara teoritis dari konsep dasar Aswaja, sikap tasamuh, i'tidal, amar' ma'ruf nahi munkar, tawazun, dan tawasuth. Dari pembelajaran Aswaja tersebut terdapat semangat nasionalisme karena diaplikasikan melalui aksi nyata seperti memelihara alam semesta dengan cara melestarikan hutan dan lingkungan hidup serta langsung terlibat dalam aksi gotong-royong di lingkungan masyarakat dan menjalin relasi baik dengan keluarga, kerabat, dan tetangga. Mempunyai rasa welas asih terhadap orang lain, saling menghormati, saling membantu, juga menjaga kerukuanan antar warga. 
Pelajaran pendidikan agama berhauan Aswaja memiliki andil besar dalam pembentukan karakter nasionalisme. Dengan member materi-materi belajar baik dari segi akidah, tasyri' (hukum) dan nilai-nilai Aswaja sehingga menjadikan peserta didik terbiasa dan dapat terinternalisasi dalam kehidupan sehar-hari. Peter L. Berger menyatakan bahwa sistem pengetahuan manusia tidak terlepas dari pengetahuan yang mengelilinginya kemudian menjadi referensi dalam kehidupan sehari-hari (Berger, 1990). Begitu juga peserta didik SD Islamiyah Magetan, dengan mengenalkan dan mengajarkan materi-materi berhaluan Aswaja dan berpegang teguh, dapat menjadi referensi dalam kehidupan sehrai-hari baik dalam berakidah sehingga terhindar dari ideologi radikalisme yang berkembang saat ini dan sikap tersebut merupakan bagian dari pencegahan dan sekaligus kontra radikalisme.

\section{PPK Berbasis Budaya Sekolah}

Aktivitas pembelajaran nasionalisme melaluia amaliah Aswaja berbasis budaya sekolah dengan menerapkan kebijakan-kebijakan atau pendidikan yang membentuk sebuah tradisi yang berkembang dan tumbuh sesuai semangat siswa dengan nilai-nilai karakter yang melekat di lembaga pendidikan. Beberapa aktivitas-aktivitas yang dilaksanakan oleh SD Islamiyah Magetan, maka dapat diklasifikasikan menjadi beberapa tema yang berisi nilai-nilai pendidikan karakter nasionalisme, yaitu:

a. Secara rutin sekolah melaksanakan ibadah bersama setiap hari Sabtu dengan Amaliah Aswaja NU yakni Tartil Qur'an dan Nadhom al-Asma al-Husna seperti mujahadah, istighosah, dan tahlil yang dipimpin oleh guru secara bergantian menurut jadwal imam salat yang sudah ditentukan. Dari kegiatan ini diharapkan mampu membentuk nilai religi, tanggung jawab, toleransi, disiplin, peduli sosial, kerja keras, jujur, peduli lingkungan, dan kebersamaan.

b. Sekolah juga mengadakan upacara keagamaan dan hari besar nasional dengan pelaksana warga sekolah.

c. Sekolah mengadakan lomba-lomba yang bernuansa keislaman dan pelatihan-pelatihan dari kebijakan yang telah ditentukan pihak sekolah.

d. Kegiatan bercerita tentang para pahlawan Islam seperti Walisongo, yang dapat membangkitkan kesadaran pentingnya nilai-nilai akhlak dan moral yang diajarkan para wali di mana didasarkan sesuai al-Qur'an dan hadis.

Kriteria pencapaian pendidikan karakter pada tataran sekolah adalah budaya sekolah yang terbentuk melalui tingkah laku, tradisi, simbol-simbol, dan kebiasaan sehari-hari yang dilaksanakan oleh semua warga sekolah yang berlandaskan nilai-nilai tersebut. Dari penjelasan tersebut, tentang 
nilai-nilai nasionalisme melalui amaliah Aswaja yang diterapkan dapat diketahui bahwa semua pencapaian indikator telah sesuai dengan nilai pendidikan karakter nasionalisme yang mengacu pada Kementerian Agama. Sehingga membentuk pembiasaan yang dilaksanakan secara terus-menerus dengan harapan dapat menjadi perilaku yang positif. Pembiasaan biasanya menitikberatkan pada pengalaman siswa yang dibiasakan secara berulang (Daryanto, 2015).

Dengan demikian, pelaksanaan dapat berhasil membentuk karakter nasionalisme siswa dengan metode keteladanan, pembiasaan, dan pembudayaan tradisi di sekolah sehingga dapat melaksanakan aturan, mentaati, dan menghargai jasa para pendahulu dengan mengedepankan persatuan dan kesatuan cinta dalam kebersamaan. Budaya sekolah adalah dasar bagi seorang siswa untuk mengalami perubahan pola tingkah laku melalui kebiasaan dan rutinitas yang dilakukan oleh segenap masyarakat di lingkungan sekolah secara efekif. Praktek berkelanjutan dengan menggunakan nilainilai positif dapat diterima dalam pembentukan karakter dan nilai melalui proses yang dikembangkan dalam jangka panjang. Proses interaksi sosial di sekolah dapat dikembangkan melalui keteladanan, pelatihan, kedisiplinan, dan pembiasaan siswa dalam konteks penguatan karakter.

\section{PPK Berbasis Masyarakat}

Pelaksanaan penguatan pendidikan karakter dapat diterapkan pada tataran praktisnya berupa kerjasama dengan organisasi masyarakat yakni IPNU atau IPPNU. Keikut sertaan peserta didik dalam kegiatan IPNU atau IPPNU dan kegiatan amaliah Aswaja lainnya dalam masyarakat dapat menanamkan nasionalisme dan kegiatan positif lainnya. Secara kultur IPNU dan IPPNU masih dalam afiliasi NU yang notabennya merupakan organisasi keagamaan yang berhaluan Aswaja yang sejak berdirinya selalu mengutamakan kepentingan bangsa dan negara didasarkan pada syariat Islam dan nilai keislaman dan keindonesiaan serta semangat nasinalisme, sehingga sebagai strategi dalam menyongsong masa depan masyarakat lebih diarahkan untuk membentuk pendidikan berbasis agamis, mental, dan emosional agar mensosialisasikan pemaknaan dan mengajarkan peserta didik tentang keimanan dan ilmu pengetahuan. Beberapa prinsip pendidikan berbasis masyarakat seperti yang diungkapkan Michael W. Galbraith dalam buku Zubaedi, yakni:

a. Self determination (menentukan sendiri)

Pada prinsip ini setiap warga masyarakat memiliki tanggung jawab serta hak dan harus terlibat langsung dalam menentukan kebutuhan kepentingan masyarakat.

b. Self help (menolong diri sendiri)

Pada prinsip ini masyarakat harus bisa menolong dirinya sendiri, sehingga mereka mampu membangun kemandirian dan menjadi solusi atas masalah yang ada. 
c. Leadership development (pengembangan kepemimpinan)

Pada prinsip ini tugas utama seorang pemimpin harus mampu mengembangkan masyarakat secara berkelanjutan, memecahkan masalah, dan siap untuk mengambil keputusan demi kesejahteraan kelompok.

d. Localization (lokalitas)

Prinsip ini mementingkan partisipasi masyarakat agar dapat berjalan maksimal, sehingga masyarakat memiliki kesempatan dan kerjasama yang harmonis untuk terlibat langsung dalam program atau rencana di lingkungan sekitarnya.

e. Integred delivery of service (keterpaduan pemberian layanan)

Prinsip ini mengutamakan organisasi di masyarakat dalam memberikan pelayanan yang baik terhadap warga sekitar secara bersama-sama dalam melayani masyarakat demi terwujudnya harapan yang ingin dicapai.

f. Reduce duplication of service (mengurangi duplikasi jasa)

Pada prinsip ini pengkoordinasian masyarakat pada jasa pelayanan seperti sumber daya manusia dan keuangan yang digunakan demi kepentingan masyarakat.

g. Accept diversity (menerima keanekaragaman)

Pada prinsip ini mengedepankan keanekaragaman dalam masyarakat, sehingga menghindari adanya perlakuan yang tidak baik yang dikarenakan oleh perbedaan jenis kelamin, ras, agama, kelas sosial, etnik, usia, yang mengakibatkan terhalangnya pengembangan masyarakat secara maksimal.

h. Institusional responsive (tanggung jawab kelembagaan)

Lembaga pendidikan harus memiliki tanggung jawab, orientasi, dan kepedulian terhadap kebutuhan masyarakat yang bersifat dinamis.

i. $\quad$ Life long learning (pembelajaran seumur hidup)

Lembaga pendidikan juga dapat menjadi pembelajaran jangka panjang yang artinya belajar sampai kapanpun sesuai dengan kriteria pendidikan formal maupun nonformal untuk semua anggota masyarakat dengan berbagai latar belakang (Zubaedi, 2011).

Dengan mendasarkan pada prinsip di atas, untuk mampu memecahkan berbagai macam problematika masyarakat, dari penyelenggaraan pendidikan yang berbasis masyarakat dituntut untuk mampu aktif terlibat dalam berbagai aktivitas yang ada di lingkungan sekitar, sehingga partisipasi dari masyarakat sangat dibutuhkan dalam mengajarkan nilai dan karakter kepada peserta didik. 


\section{Faktor-faktor yang Mempengaruhi Implementasi}

\section{Faktor Hambatan}

Dalam setiap program kegiatan yang dilaksanakan hampir dispastikan ada kendala. Di antara beberapa pelaksanaan yang dilakukan berbasis kelas, budaya, maupun masyarakat dapat dipastikan penerapan amaliah Aswaja (Ke-NU-an) mengalami beberapa faktor penghambat dan pendukung dalam implementasi di lapangan.

Pertama, media sosial yang sering diakses siswa terkadang mengandung propaganda. Memang, era milenial saat ini tak mampu menolak apa yang disajikan oleh media sosial, sehingga kerap kali siswa lebih mudah menerima dari apasegala informasi yang disampaikan oleh media sosial. Selain itu, mendadak bermunculan ustad-ustad baru di instagram, twitter, dan youtube, sehingga menjadikan siswa mudah percaya dan tidak melakukan cek ulang dengan ahlinya, terutama ahli Aswaja atau NU. Kedua, rasa tidak percaya diri dalam memaham dan mempelajari buku-buku tentang paham Aswaja. Dampak media sosial ternyata akhirnya menjadikan siswa lebih percaya diri dengan menonton video-video di yutube atau media sosial lainnya dengan ustad-ustad baru yang tidak jelas sanad keilmuannya. Hal ini berdampak pada semangat nasionalisme pada siswa sebab para penceramah banyak terpapar radikalisme dan di bawah standirisasi dai.

Persoalan di atas dapat digambarkan sebagai perilaku menyimpang dan tidak biasa, sehingga termanifestasi ke dalam reaksi publik yang menimbulkan ketakutan dalam masyarakat. Pada kelompok masyarakat yang merasa terancam oleh perubahan sosial inilah secara tidak langsung mereka mengalami moral panik atau kepanikan moral yang kemudian digunakan secara lebih luas terutama di kalangan generasi muda yang dianggap telah menyimpang dari keyakinan dan norma yang berlaku di masyarakat. Kepanikan moral terjadi disebabkan karena individu atau sekelompok orang berhadapan dengan situasi dan kondisi yang dianggap mengancam seperti tatanan sosial, kepentingan, dan nilai yang mereka anut (Cohen, 2011).

Seperti yang diungkapkan oleh Chris Barker bahwa media mempunyai peran yang penting terhadap pola perubahan tingkah laku seseorang. Dalam konsep kepanikan moral dan penyimpangan secara luas, proses keberlangsungan penyimpangan tersebut berbagai media masa menduduki posisi sentral dalam menciptakan kultur kepada pemuda. Sehingga media dapat dikatakan memberi dampak pengaruh positif maupun negatif dan memberi label kepada perilaku generasi muda melalui penyimpangan-penyimpangan tersebut (Barker, 2005). Di sinilah peran media memberikan pengaruh yang sangat signifikan terhadap individu atau siswa. Hal tersebut dapat menjadi hambatan siswa dalam belajar karena tingkah laku akibat dari penyimpangan yang digambarkan dengan siswa mengalami kesulitan belajar. Faktor-faktor yang mempengaruhi belajar terbagi dalam faktor internal 
dan eksternal. Faktor internal merupakan faktor yang berasal dari dalam diri sendiri, seperti inteligensi, bakat, motivasi, minat, perhatian, kematangan, serta kesiapan. Sedangkan faktor eksternal yaitu faktor yang berasal dari luar diri manusia, seperti lingkungan keluarga, sekolah, dan masyarakat (Slameto, 2010).

Menurut Oemar, hambatan belajar dapat diartikan sebagai suatu gejala yang tampak ke dalam dari berbagai jenis manifestasi tindakan. Segala bentuk tingkah laku dapat termanifestasi secara langsung, yaitu segala sesuatu yang menghambat atau menghalangi segala yang ditemui seseorang dalam kehidupannya secara silih berganti. Sehingga menimbulkan rintangan bagi sesorang yang dalam menjalani guna mencapai tujuan (Hamalik, 2002).

Berdasarkan hal tersebut, dapat dikatakan bahwa faktor penghambat belajar siswa kebanyakan terdapat pada siswa itu sendiri yang mana malasnya siswa untuk membaca bahkan belajar yang diakibatkan oleh dorongan atau motivasi yang lemah terhadap budaya literasi. Namun lemahnya motivasi juga dapat disebabkan oleh faktor luar sebagai pendukung seperti dukungan orang tua kepada anaknya untuk tetap mendisiplinkan belajar setiap hari. Sehingga anak menghabiskan waktunya pada dunia maya atau media sosial yang semakin merebak ini menikmati beragam media sosial seperti facebook, youtube, dan lainnya. Di sekolah kurang memperhatikan atau mempelajari pelajaran sehingga hal ini menimbulkan kepanikan moral oleh para guru.

\section{Faktor Pendukung}

Faktor pendukung ini sifatnya mendorong atau membantu memudahkan pelaksanaan program pembelajaran secara maksimal. Seperti di SD Islamiyah Magetan yang tempatnya sudah berlokasi dengan kantor Cabang Nahdlatul Ulama, memudahkan dalam pembiasaan karakter aswaja sehingga atmosfirnya pun mudah diterima dalam proses pelaksanaannya.

Penciptaan lingkungan yang kondusif sangat penting dalam pembentukan karakter peserta didik. Dengan menitikberatkan pada pembiasaan yang baik, keteladanan, dan penciptaan lingkungan yang kondusif, siswa mampu melalui berbagai tugas keilmuan. Dengan demikian, apa yang didengar, dilihat, dikerjakan, serta dirasakan oleh para siswa bisa membentuk karakter mereka. Selain itu, karakter peserta didik dapat dibentuk melalui pembiasaan dan keteladanan. Sisi materil dan rangsangan atau stimulus di dalam dan luar individu mencakup lingkungan pendidikan yang baik dari segi psikologis, fisiologis, maupun sosiokulutral (E. Mulyasa, 2013). Suatu lokasi memang menentukan sebuah keberhasilan program yang diimplementasikan. Seperti di SD Islamiyah Magetan yang memiliki struktur sosial budaya dan keagamaan yang senada dan sealiran dengan program penguatan pendidikan karakter, sehingga memunculkan situasi kondisif dengan kultur budaya yang diterima siswa. 
Sebuah implementasi pendidikan dengan tempat yang kondisif memang menjadi faktor pendukung, namun keberhasilan akan tercipta apabila kompetensi guru yang unggul juga menentukan. Seperti pembiasaan amaliah Aswaja ini, faktor kompetensi guru sebagai penggerak, pengarah, dan pembimbing memang sangat vital. Mayoritas guru dari golongan atau anggota Nahdlatul Ulma. Dengan begitu, pembiasaan itu mudah dilaksanakan serta diarahkan oleh para guru yang membimbingnya.

Kompetensi profesional guru digambarkan pada kemampuan mengajar dan mendidik maupun mengampu jabatan sebagai seorang guru. Kemampuan tersebut saling terkait dengan penguasaan materi pembelajaran dan mata pelajaran secara mendalam dan luas. Dalam penguasaan tersebut mampu menambah wawasan dan pengetahuan keilmuan seorang guru dalam mengaplikasikan materi kurikulum (Uzer Usman, 2000). Terdapat empat kompetensi yang harus dimiliki oleh seorang guru yaitu kompetensi kepribadian, sosial, pedagogik, dan professional (Mulyasa, 2008). Dengan demikian, dapat dilihat kemampuan dan penguasaan materi seorang. guru memang menjadi peran yang penting untuk menentukan keberhasilan dalam membentu karakter. Mayoritas guru yang mengajar di SD tersebut memang tidak diraguakan karena setiap hari program tersebut dilakukan oleh guru, sehingga dalam pelaksaan implementansi dapat berjalan lancar dan mendorong untuk keberhasilan program tersebut.

Faktor pendukung lainya adalah komitmen dengan orang tua peserta didik melalui komunikasi yang baik terhadap pemahaman pengutan pendidikan karakter nasionalisme melalui amaliah Aswaja. Dengan ikut mendukung serta mengawasi dalam pergaulan dan penggunaan media sosial. Orang tua menyadari kalau anak juga butuh pengawasan dan perhatian dari orang tua. Peran aktif orang tua terhadap pendidikan dan pembentukan karakter tidak hanya sekadar diwujudkan dalam bentuk menyekolahkan anak pada lembaga pendidikan saja. Namun orang tua harus ikut serta dalam memaksimalkan perkembangan dan pertumbuhan anaknya. Sarana belajar yang nyaman dan kondusif serta lingkungan yang aman, dapat membuat anak betah belajar sehingga anak bisa mengembangkan kepribadian dan kemampuannya secara optimal. Selain itu, berinteraksi dengan anak secara intelektual dan emosional dengan memberikan keteladanan yang baik, menanamkan kebiasaan yang baik bagi anak di rumah, mengadakan komunikasi yang baik, juga merupakan wujud nyata partisipasi orangtua dalam pendidikan anak (Jalal, 2006).

Bentuk komitmen orang tua terhadap program pengauatan pendidikan karakter nasioalisme melalui amaliah Aswaja dengan menciptakan kondisi yang kondusif pada anak. Penciptaan suasana kondusif meliputi pengawasan dan komunikasi yang baik dengan anak sebagai bentuk dukungan secara emosional dan intelektual. Sehingga proses sangat mendukung keberlangsungan dan 
keberhasilan program SD Islamiyah dalam melaksanakan implementasi penguatan karakter nasionalisme kontra radikalisme.

\section{Implikasi Atas Implementasi Penguatan Pendidikan Karakter}

Implikasi adalah dampak atau akibat secara langsung yang dihasilkan dari suatu program. Dalam bahasa lain disebut juga bahwa implikasi merupakan konsekuensi yang ditimbulkan dari pelaksanaan sebuah kebijakan tertentu. Hal ini dapat dilihat dari pencapaian pendidikan karakter yang meliputi tradisi, perilaku, atau kebiasaan keseharian yang dipraktikkan oleh semua warga sekolah berlandaskan nilai amaliah Aswaja.

Ada beberapa pendekatan dalam menanamkan nilai pada sebuah proses pembelajaran, yaitu pendekatan emosional, keteladanan, pembiasaan, pengalaman, rasional, serta fungsional. Pertama, pendekatan pengalaman adalah proses menanamkan nilai kepada peserta didik dengan melalui pemberian pengalaman secara langsung. Sehingga dapat memberikan peluang kepada peserta didik agar memperoleh pengalaman spiritual. Kedua, pendekatan pembiasaan yang sifatnya tanpa direncanakan terlebih dahulu atau mendadak dan berlaku begitu secara terus-menerus tanpa dipikirkan lagi. Sehingga siswa terbiasa mengamalkan konsep ajaran nilai universal secara individual dengan melalui pembiasaan pembelajaran yang diberikan kepada secara berkelompok maupun individu dalam kehidupan sehari-hari. Ketiga, pendekatan yang menggunakan rasio atau akal. Hal ini dapat dipahami dan diterima dengan melalui kebenaran nilai universal. Keempat, menanamkan nilainilai atau disebut juga dengan pendekatan secara fungsional yang merupakan memanfaatkan usaha siswa dalam kehidupan sehari-hari sesuai dengan tingkatan perkembangannya. Kelima, pendekatan keteladanan merupakan cara atau metode pendidik dalam memanfaatkan pola tingkah laku yang dapat dicontoh oleh para siswa diharapkan seorang pendidik mampu memberikan contoh keteladanan yang baik bagi para siswanya. Keteladanan tersebut dapat melalui ilustrasi atau contoh perbuatan langsung dalam keseharian di sekolah (Muhtadi, 2007). Begitu pula dengan pendekatan penanaman nilai nasionalisme melalui amaliah Aswaja dapat dilakukan di sekolah maupun di masyarakat.

Pembentukan karakter juga dapat tercerminkan pada mata pelajaran agama yang berhaluan Aswaja. Buku pelajaran agama Aswaja NU disusun sendiri oleh lembaga pendidikan SD Islamiyah Magetan. Kegiatan amaliah Aswaja yang ada di SD Islamiyah terintegrasi dengan kuriulum inti yakni K-13. Artinya, kegiatan amaliah Aswaja ini sebagai pengejawantahan dari kurikulum inti hingga penguatan pendidikan karakter sebagaimana sejalan dengan program pemerintah nawacita tersebut. Tujuan dari program ini untuk menyiapkan anak-anak siap menghadapi perubahan serta tantangan zaman yang cepat berubah, baik dalam bernegara, beragama, maupun dalam bermasyarakat. Dengan mempertebal imannya maka dapat menambah wawasan mengenai sikap toleransi, pandai dalam 
menghormati dan menghargai, sehingga menjaga persatuan karena kuat rasa nasionalismenya. Terdapat model penanaman nilai-nilai dalam pendidikan, yakni direct instruction atau pengajaran langsung, paradigma model ini mengedepankan sikap kebajikan yang luhur dan penanaman nilainilai terhadap generasi muda. Pembiasaan atau perilaku keutamaan kebajikan menjadi fokus utama (Muchson and Samsuri, 2015).

Dengan demikian, dapat dilihat materi-matri Aswaja yang diajarkan didalam kelas di SD Islmiyah Magetan merupakan model penanaman nilai-nilai yang menjadi ajaran utama dalam masyarakat. Sebab dengan materi-materi Aswaja yang memliki haluan moderat sangat dibutuhkan di Indonesia khusunya di Magetan untuk menjaga persatuan. Didasarkan pada sikap moderat ini maka untuk menjaga persatuan Indonesia sekaligus mengonter pemahaman-pemahaman tentang mengenai negara Islam atau khilafah seperti yang di dengung-dengungkan oleh HTI.

Sejumlah cara dapat dilakukan untuk mengenalkan nilai nasionalisme dengan berbasis budaya sekolah. SD Islamiyah Magetan untuk membangun kepedulian murid terhadap nilai-nilai nasionalisme. Seperti program rutin setiap hari Sabtu seperti membaca nadhom al-Asma al-Husna dan tartilul al-Qur'an, sholat dhuha, tahlil, mujahadah, istighosah. Selain itu, juga diceritakan tokoh para pejuang kemerdekaan. Lingkungan budaya (environment) dapat dipengaruhi oleh pertumbuhan, perkembangan, dan tingkah laku dari kondisi di dunia ini dengan cara-cara tertentu atau biasa disebut dengan life process. Faktor lingkungan menentukan pengaruh yang besar terhadap pola tingkah laku siswa (Hasbullah, 2017). Keberlangsungan dalam kehdupan yang sudah membudaya seperti di SD Islamiyah Magetan dengan berbagai kegiatan-kegiatan seperti di atas memudahkan dalam penanaman nilai-nilai nasionalisme di SD Islamiyah sehingga mendorong keberhasilan.

Begitu juga dengan keterlibatan masyarakat dalam penguatan pendidikan karakter yang berbasis masyarakat dengan bekerasama dengan sekolah sangat diperlukan bentuk kolaborasi dalam penguatan pendidikan karakter. Seperti SD Islamiyah merekomendasikan para orang tua melakukan partisipasi aktif dalam organisasi keagamaan pada masyarakat yang dapat membantu terbuka pada dialog antara keorganisasian dengan masyarakat, menumbuhkan semangat nasionalisme terutama menumbuhkembangan semangat siswa agar bisa memiliki pemahaman dan praktek keimanan dan ketaqwaan yang benar dan toleran seperti melibatkan anak-anak mereka dalam kegiatan-kegiatan IPNU atau IPPNU dan kegiatan amaliah Aswaja lainnya dalam masyarakat. Sekolah memerlukan kerjasama dengan intasi atau lembaga lain yang berkepentingan untuk melakukan kegiatan integral guna menyelesaikan masalah. Menyediakan human resources yang disediakan oleh organisasi sosial dapat dimanfaatkan oleh sekolah untuk menutupi kekurangan. Tujuan utama hal ini adalah untuk mempertemukan kesamaan ide dan gagasan antara organisasi sosial dan sekolah. Sehiggga dapat 
mengelaborasi kegiatan belajar mengajar (Arifin, 2012). Sebagaimana kita ketahui organisasi IPNU dan IPPNU merupakan afiliasi dari organisasi Nahdlatul Ulama. Organisasi tersebut memiliki kesamaan visi dan misi seperti dalam menanggulangi radikalisme. Kegiatan IPNU dan IPPNU lebih banyak berorientasi pada amaliah Aswaja sehingga program di SD Islamiyah tersebut dapat tersalurkan dengan organisasi ini.

Thorndike berpandangan proses stimulus dan respon yang dibentuk oleh asosiasi antara peristiwa dan pengalaman. Respon tersebut dapat dipengaruhi dari lingkungan eksternal melalui tanda untuk mengaktifkan organisme kemudian muncul reaksi atau perbuatan. Lalu respon merupakan segala bentuk tingkah laku yang muncul akibat adanya rangsangan atau stimulus. Hukumhukum belajar tersebut antara lain:

a. Law of readiness (hukum kesiapan), yakni semakin siap individu dalam mendapatkan suatu perubahan pola tingkah laku, maka semakin siap pula kepuasan individu untuk belajar.

b. Law of exercise (Hukum latihan), yaitu pola tingkah laku individu yang semakin sering dilakukan secara terus-menerus maka asosiasi tersebut akan bertambah kuat.

c. Law of effect (Hukum akibat), yakni hubungan antara respon dan stimulus yang cenderung menguat karena menggembirakan, sebaliknya akan diperlemah apabila hasilnya tidak memuaskan.(Syaiful Bahri Djamarah, 2002)

Sehingga pola tingkah laku dapat terbentk oleh lingkungan yang direspon individu dalam lingkungannya sesuai dengan rangsangan yang diberikan. Begitu juga pembiasaan amaliah Aswaja dianggap mampu memberikan dampak positif pada pemahaman keagamaan peserta didik dengan pengaruh nasionalisme melalui pembiasaan amaliah Aswaja sudah cukup untuk terhindar dari propaganda gerakan radikalisme. Sebab terbiasa dengan aktivitas-aktivitas atau amalan-amalan amaliah Aswaja NU yang mendasari sikap nilai-nilai moderat terus ditanamkan kepada para siswa di SD Islamiyah.

Strategi penguatan pendidikan karakter erat kaitannya dengan pengelolaan sekolah di mana pembentukan karakter dilaksanakan, direncanakan, serta dikendalikan dalam kegiatan pendidikan yang ada di sekolah. Pengelolaan tersebut meliputi pembelajaran, tenaga kependidikan nilai-nilai yang akan diberikan, kurikulum, pendidik, serta penilaian. Sehingga sekolah dapat menjadi media yang efektif dalam pembentukan karakter siswa. Dalam konteks ini pembentukan karakter siswa dapat dibentuk dalam budaya sekolah seprti tradisi, perilaku, serta kebiasaan keseharian dipraktekkan oleh semua warga sekolah.

Begitu juga di SD Islamiyah dalam yang bertujuan demi mewujudkan cita-cita luhur di antaranya rasa nasionalisme dan persatuan. Hasil penelitian tersebut menunjukan bahwa pembiasaan 
yang dilakukan berulang-ulang dan doktrin dapat menjadi pengaruh penting terhadap upaya internalisasi. Doktrinasi paham dan nilai Aswaja NU melalui mata pelajaran agama dengan berhaluan Aswaja di SD Islamiyah Magetan lebih sering dilakukan selama proses pembelajaran di dalam maupun di luar kelas. Penanaman nilai-nilai Aswaja yang dilaksanakan oleh guru Aswaja dinilai menjadi niatan yang sangat baik, yakni menumbuhkan saling cinta dan menghormati sesama manusia sehingga terciptanya persatuan dan kesatuan sebagaiamana tercerminkan dalam nilai-nilai nasionalisme (Aqil Siradj, Said, 2008). Dari sekian aktivitas-aktivitas yang dilakukan oleh SD Islamiyah Magetan, maka dapat diambil nilai pendidikan karakter nasionalisme, yaitu:

a. Secara rutin sekolah melaksanakan ibadah bersama setiap hari Sabtu dengan amaliah Aswaja NU yakni Tartil Qur'an dan Nadhom al-Asma al-Husna seperti mujahadah, istighosah, dan tahlil yang dipimpin oleh guru secara bergantian menurut jadwal imam salat yang sudah ditentukan. Dari kegiatan ini diharapkan mampu membentuk nilai religius, tanggung jawab, toleransi, disiplin, peduli sosial, kerja keras, jujur, peduli lingkungan, dan kebersamaan.

b. Sekolah memberi mata pelajaran agama yang termanifestasikan dalam haluan Aswaja dan kegiatan bercerita tentang para pahlawan Islam seperti Walisongo yang dapat membangkitkan kesadaran pentingnya nilai-nilai akhlak dan moral yang diajarkan para wali di mana didasarkan sesuai al-Qur'a dan hadis.

Konteks tatanan sekolah dengan karakter nasionalisme merupakan cara bagaimana membentuk kebiasaan atau budaya sekolah yang berlandaskan nilai-nilai tersebut. Dalam teori konvergen perkembangan peserta didik dapat membentuk nilai melalui lingkungan masyarakat. Selain itu dapat mengembangkan potensi dasar yang menjadi penentu tingkah laku. Guna tercapainya tujuan pendidikan potensi dasar harus selalu diarahkan dengan cara mengembangkan potensi dasar tersebut agar kebiasaan baik dapat terlaksanan di sekolah maupun masyarakat (Binti Maunah, 2009).

Nasionalisme yang bertujuan untuk kesejahteraan bersama dapat menjadi penentang bagi segala bentuk penindasan pada individu maupun kelompok suatu bangsa. Nasionalisme tidak membeda-bedakan ras, suku, maupun agama. Sebagaimana prinsip nasionalisme tentang kesatuan, hasrat untuk mencapai kemerdekaan dan hasrat untuk mencapai kehormatan bangsa. Dalam PPK termuat tiga karakter semangat kebangsaan yaitu rasa kebangsaan nasionalisme, gotong-royong, dan tanggung jawab. Menurut peneliti, materi amaliah Aswaja terdapat nilai karakter yang dapat mendukung nilai sikap nasionalisme. Di mana sikap nasionalis bisa dicontohkan dengan rasa cinta tanah air, cinta damai, semangat kebangsaan, demokratis, dan toleransi. Dalam pedoman penguatan pendidikan karakter, rasa nasionalis dapat diaplikasikan sebagai cara bersikap, berpikir, dan bertindak 
dalam mewujudkan kesetiaan dan rasa rasa kepedulian terhadap lingkungan sekitar. Di mana kepentingan bangsa dan negara lebih tinggi dari pada kepentingan pribadi atau kelompok. Sehingga diperoleh kesimpulan bahwa, nilai Aswaja yang diterapkan di SD Islamiyah Magetan sudah memenuhi indikator pencapaian dalam menangkal radikalisme yang semakin menyebar di negara kita.

\section{KESIMPULAN}

SD Islamiyah menerapkan penguatan pendidikan karekter (PPK) nasionalisme dengan amaliah Aswaja. PPK dapat dilaksanakan dengan tiga pendekatan, yaitu berbasis kelas, berbasis budaya sekolah, dan berbasis masyarakat. Pertama, penguatan pendidikan karakter berbasis kelas dapat mengintegrasikan PPK dalam mata pelajaran agama berhaluan Aswaja serta dalam bentuk manajemen kelas. Kedua, PPK berbasis budaya sekolah dilakukan tiap hari sabtu dengan melaksakan Amaliah NU yang telah terjadwal, pengembangan budaya sekolah, aturan sekolah, serta pengembangan kegiatan ekstrakurikuler (wajib dan pilihan). Ketiga, PPK berbasis masyarakat dengan menjalin kerjasama dengan organisasi atau komunitas keagamaan seperti IPNU atau IPPNU cabang NU Magetan atau lainnya. Adapun faktor penghambatnya yakni pengaruh media sosial yang sering diakses siswa terkadang mengandung propaganda. Sedangkan faktor pendukung lainya adalah komitmen dengan orang tua peserta didik melalui komunikasi yang baik terhadap pemahaman pengutan pendidikan karakter nasionalisme melalui amaliah Aswaja. Keberhasilan dalam membina anak, peran orang tua yakni dengan ikut mendukung serta mengawasi dalam pergaulan dan penggunaan media sosial. Orang tua menyadari kalau anak juga butuh pengawasan dan perhatian dari orang tua. Peran orang tua dan guru sangat dibutuhkan anak dalam upaya membentuk pribadi yang berkarakter, implikasi penguatan pendidikan karakter nasionalisme melalui amaliah Aswaja di SD Islamiyah Magetan secara bertahap karakter peserta didik akan terbentuk sekaligus mampu membentengi para peserta didik dari paham radikal sebagai bentuk kontra radikalisme.

\section{DAFTAR PUSTAKA}

Arifin, Syamsul.“Kemitraan Sekolah-Masyarakat Sebagai Upaya Peningkatan Mutu Pendidikan Di Sampang Jawa Timur”. Jurnal Humanity Vol. 8, no. 1, September (2012).

Aqil Siradj, Said. Ahlussunnah wal Jama'ah; Sebuah Kritik Historis. Jakarta: Pustaka Cendikia muda, 2008.

Bahri Djamarah, Syaiful. Psikologi Belajar. Jakarta: PT Rineka Cipta, 2002.

Barker, Chris. Cultur Studies Teori dan Praktek, terj. Nurhadi. Yogyakarta: Kreasi Wacana, 2005. 
Cohen, Stanley. "Deviance and Moral Paanics" dalam Cohen, Folk Devils and Moral Panics. London: Routledge, 2020.

Daryanto. Pengelolaan Budaya dan Klim Sekolah. Yogyakarta: Gava Media, 2015.

Hasbullah. Dasar-Dasar Ilmu Pendidikan. Jakarta: PT. RajaGrafindo Persada, 2001.

Hamalik, Oemar. Psikologi Belajar Mengajar. Bandung: Sinar Baru Algesindo 1992.

Jalal, Fasli. Peran Pendidikan Non Formal dalam Pembangunan Manusia Indonesia yang Cerdas dan Bermutu. Yogyakarta: Universitas Negeri Yogyakarta. 2004.

Junanto, Subar. Civic Education. Surakarta: Fataba Press 2013.

Kemendikbud. Konsep Dan Pedoman Penguatan Pendidikan Karakte. Jakarta: Kementerian Pendidikan dan Kebudayaan Republik Indonesia, 2016.

Kemendiknas. Pengembangan Pendidikan Budaya dan Karakter Bangsa. Jakarta: Puskur, 2010.

Kurniawan, Syamsul Pendidikan Karakter: Konsepsei dan Implementasi Secara Terpadu di Lingkungan Keluarga Sekolah, Perguruan Tinggi dan Masyarakat. Yogyakarta: Ar-Ruzz Media: 2013.

L. Berger, Peter dan Thomas Luckman. tafsir Sosial Atas Kenyataan: Risalah Sosiologi Pengetahuan. Jakarta: LP3ES, 1990.

Maunah, Binti. Metodologi Pengajaran Agama Islam. Yogyakarta: Teras, 2009.

Latif, Yudi. Negara Paripurna Historisitas, Rasionalitas, dan Aktualitas Pancasila. Jakarta: Gramedia Pustaka Utama, 2011.

Muchson dan Samsuri. Dasar-Dasar Pendidikan Moral (Basis Pengembangan Pendidikan Karakter. Yogyakarta: Penerbit Ombak, 2015.

Muhtadi, Ali. “Teknik Dan Pendekatan Penanaman Nilai Dalam Proses Pembelajaran Di Sekolah”, Jurnal Majalah Ilmiah Pembelajaran, Vol 3, No 1, 2007.

Mulyasa, E. Standar Kompetensi Guru. Bandung: Rosdakarya, 2008.

Qodir, Zuly. Radikalisme Agama di Indonesia. Yogyakarta: Pustaka Pelajar, 2014.

Shihab, Alwi. Islam Inklusif: Menuju Sikap Terbuka dalam Beragama. Bandung: Mizan, 1999.

Slameto. Belajar dan Faktor-faktor yang Mempengaruhinya. Jakarta: PT. Rineka Cipta, 2010.

Tibi, Bassam. Islamism and Islam. London: Yale University Press, 2012.

Uzer Usman, Moh. Menjadi Guru Profesional. Bandung: Remaja Rosdakarya, 2000. 
PENANGKAL RADIKALISME DENGAN PENGUATAN KARAKTER NASIONALISME MELALUI ...

Irwan Fathurrochman, Abu Muslim

Qodir, Zuli. Radikalisme Agama di Indonesia. Yogyakarta: Pustaka Pelajar, 2014.

Zubaedi. Pendidikan Berbasis Masyarakat. Yogyakarta: Pustaka Pelajar, 2006.

Desain Pendidikan Karakter: Konsepsi dan Aplikasinya Dalam Lembaga Pendidikan. Jakarta: Kencana, 2012. 